Joumal of the British Sociev for Phenomenology: Vol, 38. No. 3, Oetober 2007

\section{STATELESSNESS AND BERNHARD WALDENFELS' PHENOMENOLOGY OF THE ALIEN \\ WILLIAM CONKLIN}

An enigma permeates public international law. Multilateral and regional treaties hold out that human rights are universally shared amongst all human beings. And yet, public international law, which privileges the state as the primary juridical person, has found it difficult to address inhabitants who lack legal recognition as nationals of any state. No matter how hard legal scholars, judges, arbitrators and diplomats attempt to establish rules to protect stateless peoples, the latter invariably escape through the gaps of the international legal discourse. I shall explain why this has been so. Drawing heavily on Bernhard Waldenfels' works, I shall retrieve a territorial sense of space, a territorial knowledge and the founding birth of the territorial structure. I shall then focus upon the idea, associated with the rule of law in common law jurisdictions, of an impartial third party that adjudicates a dispute between two parties. Third party adjudication has been considered politically neutral as to the content of the claims of the disputants. The third party resolves a dispute by applying a universal rule, said to protect the territorial structure, over the disputants. I shall call this third party, the 'rule of law third'. Waldenfels reminds us that the neutral Third has permeated world history, technique, culture or all these in one.' Waldenfels offers an alternative to the nule of law third. The Third, for Waldenfels, responds to stateless inhabitants, rather than posits a universal rule, over the alien's voice and body.

\section{The Enigma}

Since World War II, states have agreed to be bound by rights that respect and protect all human beings. The preamble of the U.N. Charter states, for example, that the objective of the Charter is "to reaffirm faith in fundamental human rights, in the dignity and worth of the human person, in the equal rights of men and women." The states parties to the Chanter undertake to promote respect for and the observance of human rights [Articles 13, 55(c), 62(2)] and the "just treatment" of "non-self-governing territories" (Article 73). Shortly after the War, the General Assembly of the UN resolved in the Universal Declaration of Human Rights that the "foundation of freedom, justice and peace in the world" rested upon the "recognition of the inherent dignity and of the equal and inalienable rights of all members of the human family." The "highest aspiration of the common people" involved "freedom of speech and belief and freedom from fear and want". Human rights "should be protected by the rule of law". The Universal Declaration expressed "faith in fundamental human rights, in the dignity and worth of the human person and in the equal rights of men and women." The state parties were "determined to promote social progress and better standards of life in larger freedom." Just so that there be no uncertainty as the intent of the Universal Declaration, the preamble provided that "Member States have pledged themselves to achieve, in co-operation with the United Nations, the promotion of universal respect for and observance of human rights and fundamental freedoms." The Declaration proceeded to enumerate a series of rights which are self-described as inviolable and shared with all "in a spirit of brotherhood." The UN members followed up the Universal Declaration with two comprehensive treaties, ratified by most states on the globe. The one, the Intemational Covenant of Civil and Political Rights, guaranteed "the recognition" of "everyone" "everywhere" as a "person before the law" (Article 16). Other multitateral and regional human rights treaties have followed. International tribunals, such as the International War Crimes Tribunal for the former Yugoslavia (1995), have held out a human rights regime had "supplanted" the freedom of the state that had prevailed since Westphalia (1648):

That said, the treaties, domestic judicial decisions and judgements of domestic and international tribunals have also deferred to the inner freedom of a state to define who is a national and, by negative implication, who is an alien. If a national, one is entitled to protection by the state. If a human being lacks a nationality in any state, s/he lives in an interregnum of law and is thereby open to expulsion, sexual slavery, child soldiering, coerced displacement, and humiliating social and economic conditions. Although the general criterion of nationality has been the birth of one's parents in the state's territory (jus sanguinis) or habitation in the territory (jus soli), the state has retained the discretion to this day to decide which criterion and, indeed, how to apply the criterion to ethnic groups that do not share the national traits of the dominant nation of the state. The state has retained this freedom because the conferral of nationality has been the critical element of the domaine reservee of a stale's sovereignty. Roman law and common law had a doctrine for the stateless person: damnum absque injuria ('harm from injustice')."

Permit me to offer examples of such a spectre. First, states, such as Stalinist Russia, Nazi Germany, Uganda, Ethiopia, Kuwait, Estonia, Latvia, the Czech and Slovak Republics, have de-naturalised groups en masse by re-defining who is a citizen in their domestic citizenship laws. Second, newly independent states, such as Sri Lanka and Bangladesh, defined nationality in a manner that excluded large numbers of long-time residents in their territory. Third, certain nomadic groups, such as the Roma of Romania and the Badoons of Kuwait, have lacked a nationality in any state. So too have non-treaty aboriginal peoples of North America, New Zealand and Australia. Fourth, there are nationals who have not been diplomatically protected when inhabiting the 
territory of another state. Fifth, nationals have resided within the state of nationality only to be denied de facto nationality by virtue of their deprivation of minimal security of the person and an absence of economic or social security as required by multilateral and regional treaties. The stateless alien has lived at the mercy and good will of the state of habitation. The absence of a legal bond with a state has impacted upon security of the person, public health, housing, employment, social security, and freedom of movement within and across the border of the state.

At least two postulates reinforce the state-centric legitimacy to so categorise human beings: first, the state is considered the subject in the international legal discourse and second, the state possesses the freedom of choice inside its borders to do what it wishes unless it interferes with the actions of other subjects (that is, states). Why have these two postulates been maintained since the formation of the state system in Renaissance Italy? Bernhard Waldenfels is a philosopher who addresses this question. I intend to reconstruct some of his insights and to connect them to the apparent enigma of the international legal order. One such insight is his critique of the idea that disputes need to be resolved by a third party in terms of a rule that applies to 'everyone'. Waldenfels finds such a third party adjudicator problematic, because it represents the territorial structure which locates legal officials and other signs of the Familiar (such as nationals) inside the territorial structure's border and aliens as extemal to that border. Instead, Waldenfels introduces a phenomenological Third which responds to the state and the alien who both, in turn, respond to the Third. A dialogic relation displaces the monologic character of territorial knowledge. ${ }^{5}$ I shall explicate the phenomenological Third and, at the end of my essay, ask whether, in a world dominated by selfregarding monadic states, Waldenfels' Third is a mere utopia.

\section{The Need for an Alien External to Territorial Space}

Waldenfels helps us to understand this enigma of our times by his introduction of the notion of an "inner discourse". Although the international human rights discourse universally applies to "everyone", it has two inner discourses. The one is a state-centric discourse. The second addresses the social-cultural attachment of a human being to the territory where $s /$ he lives. The latter does not depend upon the state's conferral of nationality. Even when the state-centric discourse has been open and flexible, Waldenfels argues, the alien cannot be incorporated into the discourse. Why has that been so? To respond to that 'why' we need to identify and address the pre-knowledge and pre-scriptions which characterise a discourse.'

First, our pre-knowledge of the phenomenology of the alien is the official's image of the legal structure as territorial. Space does not exist in this view unless and until a boundary is constructed on territory. The boundary renders form to the territory. Physical signs of the boundary are important: a mound of stones, a wall, a flag, a fortress with uniformed soldiers and police, combatants with a uniform, and the like. Such a physical boundary helps to identify a requisite condition for the existence of a state. Of the four basic conditions for the recognition of a territorial space as a state, one is the possession and the claim of ownership of the territory. Once the territorial boundary is closed from the outside, the legitimacy to posit laws is plenary and the coercive authority monopolised by the territorial structure.

What is interesting about this territorial sense of space is that an object inside and outside the structure's boundary is perceived as a physio-chemical mass. This mass can be located as if a mark on a map. Longitude and latitude become the co-ordinates of description of the mass. The mass may be surveyed. An official perceives the mass on the enclosed territory. The body may be observed scientifically.

As a consequence of this territorial sense of space, the context-specific experiences, interests and values of the alien cannot be coherently known. It is easy to read the alien as 'off the map'. Western legal philosophy has described the "barbarian" (Cicero, Hegel and J.S. Mill), "creature" (Hobbes), "wolf" (Hobbes), "savage" (Locke and Kant), "primitive" (John Austin and Hans Kelsen) and "pre-legal" (Hart) in such a manner." Only units inside the territorial structure are objects of the state-subject. The mass on the other side of the territorial boundary cannot be known. The exteriority is the place for "the "wild" or chaos. Nomadic tribes, for example, lack such a territorial sense of space and, as such, they have been traditionally excluded as beyond discussion or legal status in common law jurisdictions ${ }^{10} \mathrm{~A}$ trenty is considered binding upon a state only if the state has agreed to be bound. A tribe or clan has not been recognized as a state. The stateless alien has been imagined with horror alieni. The sting of the alien destabilises the territorial legal order with anxiety and fear."

If located outside the boundary of the subject's territory, the mass is passive or "acted upon". If lacking a nationality in any state, the human being is a mere physical mass. As such, it lacks personhood and, therefore, rights. The alien is just a thing. Not surprisingly, this fed an unlimited desire to possess territory as characterised by European colonialism and imperialism. Even today, aboriginal peoples may lease territory but not claim title to it in a 'developed' state such as Canada: the state alone, as the subject of international law, claims "ultimate title" or "underlying title" of all territory within its borders."

\section{Territorial Knowledge}

There is a second reason why the stateless alien lacks legal recognition. Legal knowledge is territorial. The legal official only claims to know the units which exist inside the boundary. If objects are known as legal knowledge, they 
are recognisable as analysable units on the territorial structure. The knowledge confers form to the otherwise physio-chemical mass. The masses become objects of knowledge.

The exteriority of the territorial knowledge is unknowable. It is located exterior to the boundary of territorial knowledge. In order to have order, that is, there has to be disorder. In such a discourse, legal knowledge begins and ends with an inter-connection of institutions that represent an enclosed territorial space. Thomas Hobbes, for one, explains that civil society begins to take form when authors, who have acquired conventions as to what sounds and marks signify (that is a language), begin to place borders around their territory. ${ }^{13}$ The objects locatable inside the territorial boundary also confer form to the boundary of the territorial space. The legitimacy of the state's action proceeds accordingly. Today, at best, the exteriority is considered soft law, policy, or 'oughts'. Waldenfels describes how the exteriority to territorial knowledge is totally incomprehensible, arbitrary, nothingness, barbaric, evil, chaos, and lacking in reason. ${ }^{14}$ The other side of the territorial boundary lacks familiar concepts, let alone a familiar language, customs, or religion. If the human being finds her- or himself exterior to the territorial knowledge of the "we', she cannot be analysed, observed, or perceived as knowable. Even if the alien shares the same language, customs and religious practices as the analysable units inside the territorial boundary, s/he is not even a knowable object.

Without addressing the substantive pros and cons of the content of an analysable unit, the primary legal issue, in a territorial sense of legal knowledge, concerns the vires or boundary of an official's action. One version of this is Joseph Raz's "sources thesis". Is If a rule is posited by the appropriate institutional source - such as a government agency or Minister or court - then the rule is considered authoritative. The sources thesis recognises the freedom of the state to be free so long as its decisions and actions are self-regarding. An impartial domestic court has difficulty to evaluate the content of state action unless the action causes other-regarding harm just as J.S. Mill described over a century ago. ${ }^{16}$

Thus, the territorial space, within whose space the alien happens to be located, is the state/subject's space. The state/subject possesses such an alien as an unknowable mystery. The human being, as an alien, exists only to the extent that legal consciousness encodes the mass as a sign that represents a legal category such as 'illegal' or 'alien' or 'migrant'. Although the alien constitutes acts of meaning which draw from her or his felt experiences, "the state-subject need not respond to such acts of meaning. The alien's meaningconstituting acts, of necessity, remain unrecognised and unrecognisable as units of legal knowledge of the state/subject. Legal knowledge ends at the border of the state. ${ }^{18}$ The biological and experiential body of the alien may be reconstructed as a legal form that can be continually re-formed without harming, denying or including the meaning-constituting act of the alien in the dominant state-centric discourse. The juridical official does not need to take any responsibility for this exclusionary decision, for the official represents the standpoint of the territorial structure. The analysis of concepts, knowable because they are located inside the territorial boundary, immunises the judge from the meant objects of the alien who is neither legal nor illegal. ${ }^{19}$ The stateless being lives in an objectless world which territorial knowledge cannot recognise.

Of course, the legal official may insist that s/he does respond to the alien and does speak on behalf of 'everyone'. It is just this universalist claim in a territorial knowledge which reinforces the blind spot of territorial knowledge, for the concepts authorised by the territorial structure unmake the alien's meant objects and thereupon re-code such objects into the official language of the structure. The official language of the state-centric legal order is monologic vis-à-vis the stateless alien because the alien cannot respond through her/his own significations of meaning-constituted objects. The latter are thereby transformed into claims, arguments and evidence recognisable and therefore known in territorial knowledge.

In this way, the universalist signs of the human rights treaties presuppose a territorial knowledge that pre-structures the aliens' own languages. Even the voice of a legal 'alien' is an indirect voice that restates the alien's concerns through a vocabulary and genre of an inner state-centric discourse. The sign, 'alien', makes sense to officials if the sign can be coherently fit into the official structure of thought, institutional structure or narrative structure about nationals (and, therefore, about 'aliens'). The alien, as a being with her/his own meanings, is re-cognised by officials as a legal or illegal alien with metaphysical boundaries that enclose the being. All human beings and all physical objects within the border of the territory are objects to be possessed by the state, like worms at the end of a fishing rod. The official legal discourse re-presents the alien as a category that can be analysed: that is, that can be decomposed into increasingly minute categorical elements. Legal knowledge is a Vor-stelling.

The alien's meant objects, unlike medical, scientific, chemical or psychological discourses, are thereby transformed into the categories of the official inner discourse that is enforced against unrecognizable human beings. The knowable units of legality are nules. The official accesses justice by decomposing the rules and then rationally linking the shared features of the micro-parts to the intent of the founding fathers of the constitution. Further, the state possesses the monopoly of coercion to universalise the transformation. The alien, as an experiential being, passes into the signifying configuration which constructs the boundary (vires) of the territorial structure. 
The official does not and cannot hear the voice of the alien except through the official discourse. The alien remains 'uninvolved' or silent as the object of the subject-state's desire. Nor does the alien, as an experiential being. hear the officials when they order her/him expelled through the language of the subject/state. As a consequence, the alien, who is neither legal nor illegal, lives in a twilight between the legal and pre-legal, legal knowledge and nonknowledge, order and disorder. Her/his lived meanings dwell in an unknowable "abyss" which lies behind every universalist claim. ${ }^{30}$

\section{When Time Begins}

There is a third factor that contributes to an explanation as to why stateless aliens remain unrecognised in a discourse claiming universal human rights. Since the state takes form when officials enclose territory with a border, legal time begins with the founding fathers of such a territorial structure. In English common law, best pronounced in Campbell v. Hall (1774), this foundation usually involves an act of conquest, discovery or settlement of the territory. Such a beginning is signified by the posting of a flag, supplemented with a fortress or military outpost. Such signs represent the ownership claim of a territorial structure. Even though eleven million may live in the territory, such as in North America before the Europeans established their territorial structures. their numbers are unrecognised as if the territory were terra nullius, because it lacks territorial structures. Time also begins with the written constitution authored by the founding fathers of a revolution. Thus, the birth of the structure supplements the physical borders so as to distinguish the legal order from the "beasts" and "wolves".22 The writing of founding authors contrasts with unwritten customs, whose origins, as Antigone expressed, is unknown to us. Time is linear from the birth of the structure into the future. The birth of a structure is distinguished from the "pre-legal" time when inhabitants are "bonded" together by "unofficial rules" based upon "kinship, common sentiment and belief."' Legal philosophers can address issues of justice only after such a birth. Because the universalist discourse privileges the state-centric inner discourse, the birth of the state becomes the critical moment in explicating legal authority and, therefore, whether an inhabitant 'exists' as a legal object.

As a consequence of this beginning of legal time, what happened to the human beings before the foundation of the territorial structure is immaterial to legal knowledge. Such an experiential time is pre-legal. The felt experiences before legal time are excluded as non-knowledge. Philosophers are "haunted" by such a pre-legal experiential time, as $H$. $L$. A. Hart notes on several occasions, because such a bonding is ultimately forgotten in the quest for territorial knowledge. The territorial knowledge represents the stateless alien without hearing or responding to the voice of the alien except as a remainder, a policy, or 'morality".
5. The Third as a 'Neutral' Judge of the Territorial Structure

So long as we presuppose a territorial sense of knowledge, Waldenfels claims, we shall fail to respond to the lived meanings of aliens. Waldenfels offers us a different sense of knowledge. A key to his contribution is his notion of the Third. To appreciate his contribution in this context, we need to remind ourselves of the role of a judge. Territorial knowledge raises disputes about boundaries. A judge is held out as an impartial, politically neutral third party who will resolve such disputes from a distance, as it were. The focus on boundaries lifts the judge from the content of rules that transcend the felt experiences of the litigants. The litigants are represented through the indirect voice of an expert of the court's judgements. The territorial knowledge posits universals that vertically transcend the meant objects of judge, state officials and alien. ${ }^{2 t}$ All are categorised as universals, Such universals rationally bridge over the alien's body and incorporate it into the territorial structure. ${ }^{3}$

Because territoriality is the basis of legal knowledge, the alien, as a mass, reminds the officials that there is a remainder to its assimilation of all objects into the legal discourse. The mass is located on a map. A court guards the very boundary that excludes such a mass as a remainder to legal discourse. Indeed. H.L.A. Hart and Joseph Raz, leading Anglo-American legal philosophers, have emphasised how the legal official must take the point of view of the structure as a whole when judging a dispute. ${ }^{\ngtr}$ The stateless alien is the sting that the territorial structure just cannot access as knowledge. Mystery surrounds such a remainder, for the voice of the remainder can only be heard as an analysable unit in the territorial knowledge. The alien cannot respond to the judge except through the judge's language. The alien must accept the judge's decision. Further deliberation about the alien's felt experiences is foreclosed. The alien cannot respond through her/his own language.

The rule of law third thereby expresses what Waldenfels describes as one mood of the single logos. ${ }^{n}$ The felt experiences of the alien become an instance of the universal categories pronounced on behalf of the territorial structure. ${ }^{20}$ Such a dominating inner discourse especially prevails during alleged emergencies when the state officials claim that the life of the territorial structure is at stake. The very impartiality and neutrality of such a rule of law third distances the judge from the collective biography of an alien who lacks legal status. The universal right to "recognise" "everyone" "everywhere" "before the law", as held out in human rights treaties, thereby becomes a "circulating totalization" [zirkulierende Totalisierung]." Indeed, the neutral tribunal stands for everyone, and yet the instance of the alien dissolves into the totalising rule of law third without being able to respond to it.

Now, what is the relation of the rule of law third to the sense of territorial space and measurable time which I elaborated earlier? Maurice Merleau-Ponty goes some distance to join these phenomena together. When the third party 
considers the alien as a measurable thing in an objectless externality, the alien is imagined. ${ }^{30}$ The official of the territorial structure cannot know the preconstituted meanings of the stranger before and until the territorial knowledge constitutes the other in the official consciousness." At that moment, officials "encroach" upon the alien as they reflect about the other as a category that hides the other's pre-constituted meanings." The official language separates out the body of the alien as a physical mass rather than as the embodiment of meaning. As such, the "reflection" of the universalising discourse, such as the universalist human rights discourse, reconstitutes the consciousness of the alien to the point that it "masks" the meaning acts of the stranger's body "outside of time" body, the phenomenal body of the official and of the alien are works of art as they move towards and with the ambiguous meaning act of the other. ${ }^{34}$ If the Third were a relative factor vis-dे-vis the alien, the Third would retrieve the collective memories and meaning-constituting acts which remain nested inside the re-constituting of the alien in legal consciousness.

Connecting this to international legal discourse, if the state justifies its expulsion of individual human beings before the rule of law third whose creation, assumptions and expectations reinforce the way of thinking of the expelling state, then the latter effectively determines the outcome of the dispute between the state and the expelled alien. The latter inner discourse perpetuates the territorial separation of the alien from the expelling state under the Third's colour of neutrality, objectivity and detachment. Further, the state retrospectively imposes its justificatory acts upon the alien's experiences of suffering." Lawyers and judges take a point of view that reinforces the apparent neutrality and objectivity of the international legal structure as a whole at the same moment that a violent inner discourse cannot hear or respond to the alien. ${ }^{36}$ Thus, an appeal to the universal and impartial 'rule of law', administered by an over-bearing neutral third-party judge, does not erase the violence of the territorial structure against the alien. The alien still moves in a different direction from the rule of law third. In this way, a territorial, atemporal analysis displaces "interrogation" with "reflection", Merleau-Ponty explains. ${ }^{37}$ The best that the official can do, familiar with her or his own Heimwelt, is to picture or imagine the alien as a physical thing whose 'natural' locus is on the other side of the border. As a consequence, the alien's meaningconstituting acts, embodied with the space of felt experiences and the time of collective memories, remain 'incomprehensible' to the officials of the expelling territorial state.

Because the totalising state-centric discourse assumes the border that separates the territorial space of an expelling state from the 'rightful' locus of the alien on the other side of the border, even an universalist claim, such as one finds in human rights treaties, need not access and cannot access the alien's meaning-constituting acts. The alien, located in the pre-legal unknowable, remains a mysterious "phantom" that "haunts" legal analysis." As a consequence, the alien's meaning-constituting acts escape the universal human rights' discourse which, I repeat, territorialises knowledge.

The physical border of a territorial structure, then, marks off the freedom or privacy of the structure to decide about objects within its territorial knowledge. The border separates an inside from an outside, an 'is' from 'ought', the state's authority from the authority of another state, a national from an alien.' The border immunises the subject's inner sphere of life from the evaluative scrutiny of others, let alone from physical invasion by any other territorial unit. Inside the border, the subject is free to authorise legal action against its inhabitants and to exercise a monopoly of violence disguised as the rule of law'. The intemational legal order aims to protect such an inner sphere of life of the subject state. Thus, the territorial space marks the domaine reservée of the state-subject of the international legal order. Such a domaine may be only restricted with the subject-state's consent in the form of a treaty. The question 'who is a national?' is otherwise left to the inner sphere of life of the territorial state.

\section{The Phenomenal Thind}

Now, Waldenfels offers an insight that plays to the above enigma of the state-centric territorial knowledge. Instead of the rule of law judge making a decision, which thereafter, by virtue of being a decision, excludes a deliberation about the content of the decision, Waldenfels raises the possibility of a phenomenal Third. The Third speaks as a third party independent of the state and the alien. The Third responds to the voice of the 'we' and responds to the alien's voice. Here, the alien would not have to justify her/himself to a rule of law third. The latter, after all, represents the territorial structure, not norms that are independent of that structure. With a phenomenal Third, the Third, the territorial structure and the alien each responds to the other's response and their responses, in turn, would respond to each other's responses. The dialogue takes on a life of its own. The judge is no longer a neutral umpire who decides, guides, directs or enforces general rules. The alien is not known as a universal rule.

Instead, the alien is not determined in "a complete and univocal sense." The alien is 'known' as a respondent, not a subject or object. To the extent that the alien differs from the state or the Third, it is not a territorial difference but a "responsive difference". In this light, because of the relative and responsive relation of the alien with the Third and vice versa, there is a sense of the state in the alien and of the alien in the state. As Waldenfels describes, "[t]here is neither a sovereign speaker or actor preceding the responding nor a judge considering both sides; the respondent ... becomes what he is by and in the 
very process of responding." The phenomenal Third is the dimension of experience that legal officials have heretofore concealed in their appeal to a neutral rule of law third. The phenomenal Third interrogates not only the self but the familiar and the stranger so that neither might consider itself an absolute.

This responsive relation is not the sort of dialogic relation that Habermas privileges. $^{41}$ To the contrary. Habermas' dialogic relation, according to Waldenfels, illustrates precisely the type of responsivity that is not really dialogic. ${ }^{22}$ For, in my context, Habermas' dialogic relation risks a reinforcement of a state-centric discursive structure with its own territorial parameters as to whether evidence must be documentary or oral, what counts as relevant evidence, weighty evidence, standing, the role of the official, the authorising origin of the legal order as a whole, the method of reasoning, and the analysable units (rules, principles, policies, written standards, unwritten expectations, ethical, political). Such a framework of argument and evidence encourages the rule of law third to write and speak without the alien possessing an opportunity to respond. The rule of law third is anonymous in such a view and yet, it plays the role of everyone. Even the offrcials, who represent the rule of law third, stand above the things [eines Drinten, der über den Dingen steht]. The rule of law third has "a communicative indifference" [eine kommunikative Indifferenz] of the stranger. ${ }^{33} \mathrm{~A}$ monologue by one logos dominates. A seemingly neutral, objective and distancing judge becomes the voice of the perpetrator of violence. ${ }^{4}$ Both the alien and the phenomenal Third lack a common or universal scale with which to respond to each other. This is so even if the legal order is open and flexible. ${ }^{45} \mathrm{As}$ a consequence, the appeal to the rule of law third legitimises the violence of the familiar against the alien.

In contrast, the phenomenal Third and officials of the territorial structure respond to the alien and the alien to them in terms of experiential time. The most important constituent of experiential time in this context is the collective memory of the alien. Karl Jung distinguished between a personal and a collective memory. ${ }^{46}$ The collective memories that induce a bonding are transferred from generation to generation. Acts of genocide and mass expulsions play no small role in such collective memories. A personal memory, in contrast, may be repressed or forgotten and yet recovered with some effort. One is conscious of the experience at some point in (experiential) time and, therefore, one can, with effort, bring it back to consciousness. But when a collective memory takes hold of officials (or aliens), the structural assumptions of the collective memory precede the individual's experiences and immediate decisions. The traditional approach of the rule of law third, which treats a dispute as an individual dispute between two individual parties, misses the importance of collective memory that experiential time induces. ${ }^{47}$
The collective memory is drawn from a discursive, not a territorial, context and a context that is specific to the felt experiences of the alien. The rule of law third had pictured the alien as crossing into a boundary-less wild that we legal officials just could not know or analyse as an object. In contrast, the phenomenal Third keeps all subjects and objects awake by responding to them as respondents. It does so because the lateral universal of the Third is not mediated by a transcendent universal (such as 'the right of a lawful alien not to be expelled except in accord with law'), nor by a primordial common nature between the 'we' and the alien (such as a dignity shared by the human species), but by "the wild" or "boundary-less uncertainty" of the twilight of legal consciousness. Waldenfels describes the phenomenal Third as a "spontaneous philosophy whose truth ... goes beyond the method" [einer spontanen Philosophie, deren Wahrheit ... über sie (sc. die Methode) hinausgeht]. ${ }^{43}$ The phenomenal Third makes possible another seeing, thinking and acting. ${ }^{9}$ The Third now implicitly or explicitly treats the alien as someone whose meaning-constituting acts are worthy of response. The Third hears and responds to the voice of the alien and, contrary to Jacques Derrida, ${ }^{30}$ the phenomenal Third raises the possibility that law can be just.

The phenomenal Third responds to the discursive world view of the alien as well as of the state. The responses of the one to the other induce a "way of thinking" that changes all three. ${ }^{31}$ So the state thereby transgresses its own territorial and a-temporal knowledge of lawfulness, national security and 'who is an alien'. The alien, as a consequence, is never utterly alien to the state and the state is never utterly alien to the alien. Both are subjects, as is the Third. As noted above, there is an alien in the 'we' and a 'we' in the alien when the phenomenal Third takes hold of our understanding because, in place of the territorial knowledge that postulates a border between the we and the stranger. the Third and the state respond to the alien's responses to its responses. The phenomenal Third raises the possibility that dialogue is not the basic relationship. Dialogue derives from a deeper sense of responsiveness. This possibility sets the condition for the Third to "return" to the stranger as an instance ${ }^{52}$ or perhaps what might be considered an addressive experience. ${ }^{53}$ As this sense of the phenomenal Third takes hold of human action, the territorial boundaries of the state dissipate, the artificial a-temporality of legal knowledge fades and the strangeness of the alien is displaced in favour of someone who is deserving of responses and of responding.

\section{Is the Phenomenal Third an Idealised Image?}

There is a small problem with Waldenfels' sense of the phenomenal Third: namely, that the state-centric discourse is having its day in the wotld in which we live. The international legal order seems to be returning to the presupposed monadic state that acts as if its identity did not depend upon other states for its 
very existence or survival. Such a view of international law finds war and aggression commonplace, just as the displacements of populations, sex slavery, torture and expulsions appear to be beyond buman control. Is it not the case that Waldenfels' Third and the possible institutionalisation of experiential space and time are the product of naivete? What role is there for the phenomenological theory of the alien in such circumstances?

First, the state-centric inner discourse is only one inner discourse of international law. There is another which I have introduced elsewhere. ${ }^{34}$ Instead of territorial space, this second inner discourse examines the sociocultural attachment of an inhabitant to a territory independently of the laws of the state of habitation. Such an attachment incorporates the collective memories, beliefs, social practices, customs, and ideals which the alien experiences and has experienced as a member of a group. This socio-cultural attachment to territory defines one's nationality. Further, the cluster of rights about one's attachment to territory explains why important international customary norms are peremptory. The Vienna Convention on Treaties, Article 53. defines a peremptory norm as "a norm accepted and recognised by the international community of states as a whole." The kernel of a peremptory norm is that there are norms that provide the structure of the international legal order which, in turn, privileges the territorial structure as the primary juridical subject. Any treaty or state action that contravenes such norms is void (Article 64). Although tribunals and commentators disagree as to what are such structural pillars, there is a consensus that certain peremptory norms protect the socio-cultural attachment of the human being to a territory. Discrimination on the grounds of the conferral of nationality and national origin are commonly accepted norms attested by most states on the globe. The Hague Conventions from 1949 define a "grave breach" of a crime against humanity and a war crime as mass deportation and forcible transfers of a populace, whether inside or outside the territorial state structure. The statutes that established the intemational criminal tribunals of Nürnberg, the former Yugoslavia, Rwanda and the permanent international criminal court at the Hague have recognised the mass deportation and forcible displacements of a populace as cause for prosecution. Sex slavery and genocide, which usually go hand in hand with statelessness, are also recognised as "grave breaches" of international criminal law. What is most important to appreciate in this regard is that the violent disrespect of the inhabitant's attachment to a territory is not a harm caused to a state but to the international legal order as a whole. The duties of the territorial state to the inhabitant's attachment to the state's territory are erga omnes. Cicero was not the last jurist to recognise the erga omnes as the foundation of legality. And the erga omnes addresses the experiential place and time of which Waldenfels has so exhaustively reasoned.
If there are such norms that proscribe a territorial structure from failing to protect a stateless inhabitant independently of territorial knowledge, the charge of naiveté remains, for the primary enforcer of such a proscription, in a state-centric inner discourse, is the state itself. That said, a plethora of legal remedies, criminal and civil, have taken hold of lawyers since the early $1990 \mathrm{~s}$. States are increasingly enacting criminal law amendments to recognise the criminal state action that offends the socio-cultural bonding of an individual to her/his territory of habitation. It would heve been inconceivable in the early 1990s that, despite the objections of the remaining world power, there would be a permanent international criminal court within only ten years. The 'Committee' established under the International Covenant of Civil and Political Rights, 1965, which most states on the globe have ratified, has evolved into a quasi-judicial tribunal. A territorial structure may launch a complaint before the committee against another for the latter's violation of the above-mentioned peremptory norms associated with territorial attachment. By virtue of the Optional Protocol of the treaty, any individual inhabitant of a state party to the treaty may also launch a complaint against any state party. This Optional Protocol is the model precedent for other multilateral and regional human rights treaties. Indeed, the social science and anthropological evidence as to the collective memories of aliens that would be excluded in a European state-centric legal order of an earlier day are now being admitted as evidence in domestic and international tribunals. Intentional torture, caused by a foreign state official to a United States inhabitant, is the cause for a civil remedy in the United States. Civil remedies, including actions for false imprisonment, assault and other torturous acts, are expanding to warrant future possibilities for the legal protection of groups of aliens. Class actions on behalf of displaced stateless persons have, of recent years, been launched before international arbitration tribunals and the international court. Nongovernmental organisations have become important representatives of ethnic groups whose attachment to a territory has been violated by states. International legal discourse is increasingly becoming sensitive to the experiential space and time which characterise the alien.

An accounting before a phenomenal Third is now a possibility. That said, Waldenfels himself acknowledges that analysis arrives on the scene after the alien's felt experiences have been harmed. And Hegel reminds us that the owl of Minerva begins its flight only with the onset of dusk. Lawyers and judges enter a dispute after the harm has been caused. Writs of injunction and of prohibition by some international tribunal are not likely to help to prevent the territorial state from committing atrocities to stateless aliens. There is one little point that needs to be kept in mind, however. A law suit is a civil war by peaceful means. A legal process takes on a life of its own independent of the control of the litigants. Precedent chills action. Unlike a machine, though, it is 
difficult to stop the legal process once it has begun. Universal human rights norms will effectively chill state action, as the American prosecutor at the Nümberg Tribunal recognised, when the victors are charged, prosecuted and convicted for their crimes against humanity. The phenomenology of the alien is nested in the wings of the owl of Minerva. To be sure, the owl of Minerva does not begin its flight until after harm has been committed to humanity. The owl of Minerva, though, does begin its flight at dusk.

\section{University of Windsor, Canada}

\section{References}

1. Bernhard Waldenfels, Topographie des Fremden. 4 vols. Studien zur Phänomenologie des Fremden. 2nd ed. (Frankfurt an Main: Suhrkamp Verlag 1997) vol, 1, 118, from now on referred to as SPF. [Fremden].

2. Prosecutor 4. Tadic Appeals Chamber, Intemational Court for the Former Yugoslavia, 1995 Case No, IT-94-1-AR72, 2 October 1995, http:/www.un.org.icty/ladic/appeal/decisionc51001.htm Para. 97

3. One treaty grants legal status to "stateless persons". But only 42 states have ratified said treaty.

4. Indeed, it is not a coincidence how often de jure or de facto statelessness has accompanied detention without trial, expulsion, intemal displacement, torture; sex slavery and the sexual abuse of girls and women have been directed against stateless persons.

5. For the monologic character of a modern legal discourse see William E. Conklin, Plienomenology of Modem Legal Discourse (Aldershot: Dartmouth, 1998), from now on referred to as Phenomenology.

6. Waldenfels, SPF, p. 126.

7. Waldenfels, "Interrogative Thinking: Reflections on Merleau-Ponty's Later Philosophy" in Merleau-Ponry in Contemporany Perspective, P. Burke and J. Van der Veken eds. (Dordrecht: Kluwer, 1993), 3-12.

8. A state has had to possess a territory, a population, a govemment (in a centralised bureaucratic sense expected of Western Europear states), and a effective capacity to enter into relations with other states.

9. Actually, Hegel describes the stateless peoples as "savage", "barbaric", "primitive", "animalistic" and "hordes". Kant describes stateless peoples as inferior, lazy, diry, and "animalistic" and "hordes". Kant describes stateless peoples as inferior, lazy, dity, and Evil" in Public Culture 12 (2000): 529-64, at 532-36.

10. Hobbes, Thomas, Leviathan, C.B. Macpherson, ed. (Harmondsworth: Penguin, 1968), p. 187, 378; Locke, John, Second Treatise of Government, Peter Lastett, ed., Two Theatises of Government (Cambridge: Cambridge University Press, 1960), para. 48-9.

11. Waldenfels, Order of the Twilight, David J. Parent, trans. (Athens: Ohio University Press, 1996). 114-16. Twilight. Trans. of Ordmung imt Zwielich (1987). Also see Waldenfels, Der Stachel des Fremden 3rd ed. (Frankfurt am Main: Suhrkamp Verlag. 1997).

12. Guerin * The Queen, [1984] 2 SCR 335. SCC.

13. Compare: William E Conklin, The Invisible Origins of Legal Positivism; a Re-Reading of a Tradition (Dordrecht: Kluwer, 2001), pp 80f, [Imvisible Origins].

14. Bernhard Walderfels, Twilight, pp, 66-9.

15. See esp. Raz, Joseph. "Authority, Law and Morality". Monist 68 (1985): 295-324 and reprinted in Raz, Eshics in the Public Domain (Oxford: Clarendon Press, 1994) 210-37.

16. J.S. Mill, "A Few Words on Non Intervention" in Essays on Equality, Law and Education with intro. by Stephan Collini. 33 vols. Collected Works of J.S. Mill, John Robson ed. (Toronto: University of Toronto Press, 1984), vol. 2, 111-124.
17. Edmund Husserl, Logical Investigations. 2 vols. (New York: Humanities Press, 1970), vol. 2. $560-62$.

18. Maurice Merleau-Ponty, Prose of the World, John O'Neilt, trans., Claude Lefon ed. (Evanston: Northwestem University Press, 1973). 103-04 [Prose].

19. The distinction between a meant and posiled object is elaborated in Conklin Phenomenology, pp. $51-68$.

20. Waldenfels, "Response and Responsibility in Lévinas" in: Adrian T. Peperzak ed.. Efhics as First Philosophy: The Significance of Emmanuel Lévinas for Philosophy, Literature and Religion (New York; Routledge, 1995), 39-52, at 41 ["Response"]

21. Campbell v: Hall 1 Cowp. 204, 98 E.R. 1045.

22. Hobbes, 187,378

23. Hart. 92.

24. Waldenfels, SPF, p. 101.

25. lbid. 86, 86.

26. See, e.g., Hans Kelsen, The Pure Theory of Law, Max Knight trans. (Berkeley: University of California Press, 1970), 218 at fn 82; Joseph Raz, The Authority of Law (Oxford: Clarendon, 1979), 140; H.L.A. Har, The Concept of Law 2d. (Oxford: Clarendon, 1994), 57-61. Raz argues that the official must be "committed" to the structure.

27. Waldenfels, SPF, 86.

28. Waldenfels ibid, 123

29. Waldenfels ibid. 115, quoting from Sartre.

- 30. Maurice Merleau-Ponty, Phenomenology of Perception, Colin Smith trans. (London: Routledge \& Kegan Paul, 1962). 100ff. [Pereption].

31. Maurice Merleau-Ponty, , "The Phenomenology of Language" in Signts, Richard C. McCleary Irans. (Evanston: Northwestern University Press, 1964), 84-97, at 95. ["Language"].

32. Merleau-Ponty, Prose, p. 139.

33. Ibid. p. 144.

34. Merteau-Ponty, Perception, $174-99$.

35. See generally Conklin "The Trap" in Law and Critique 13 (2002): 1-28: and Phenomenology.

36. Waldenfels, SPF, 117. Also see ConkJin, Phenomenology, 69-101 and Invisible Origins, 269. 73 .

37. Merleau-Ponty. Perception. p. 31 I. Also see Merleau-Ponty. "Reflection and Interrogation" in The Visible and the Invisibie, Alphonso Lingis trans. (Evanston: Northwestera University Press, 1968). 3-49

38. Hart, op. cit. 87.

39. Waldenfels, "Response", "Response to the Other" in Encountering the Other(s): Studies in Literature, Histon and Culture, Gisela Brinker-Gablen ed. (New York: Stale University of New York Press, 1995), 35-44, at 43.

40. Waldenfels "Response", p. 42

41. Waldenfels, SPF, p. 116

42. Waldenfels is critical of both contextualists and universalists for they assume that communication or 'dialogue' can actually occur between the 'we' and the alien when the neutral Third presides over their disputes, as if a boundary separated the familiar from the stranger. Ibid., p. 117

43. Wid.

44. Waldenfels, "Response", p. 40

45. /bid. and SPF, p. 126.

46. Karl Jung. "The Concept of the Collective Unconscious" in Walter K. Gordon ed, Literature in Critical Perspective (New York: Appleton-Crofts, 1968), 504-08 at 506.

47. There is a sense in which. as Waldenfels describes of the Nazi genocide, the adjudication of individual cases by the Human Rights Committee cannot be compared with the extraordinary 
mass expulsions of the recent dark century. "DaB jeder. der eine Singularitit von Menschheitsverbrechen nur im Singular, nicht aber im Plural zuläBt, doch wieder relativiert, indem er alle Verbrechen an einem historischen summum malum miBt, dbersieht man nur allzu leicht", SPF, p. 128.

48. Ibid, p. 101.

49. Ibid, p. 121

50. Derrida, Jacques. "Force of Law: the Mystical Fountation of Law". Candozo Law Review 11 (1990): pp. 919-1045, p. 948: “S'adresser à l'autre dans la langue de l'autre, c'est à la fois la condition de toute justice possible, semble-t-il, mais cela parait non seulement impossible en toute rigueur (puisque je ne peux parler la langue de l'autre que dans la mesure où je me l'approprie et l'ussimile selon la loi d'un (iers implicite) mais metme exclu par la justice comme droit en tant qu'elle semble impliquer un elément d'universalité, le recours au tjers qui suspend l'unilatéralité ou la singularicé des idiomes".

51. Waldeniels, SPF, pp. 101, 116

52. Waldenfels, "Experience of the Other: Between Appropriation and Disappropriation" in Stephen K. White ed., Life-World and Politics: Between Modemity and Postmodernity. Ersays in Honor of Fred R. Dallmayer (Notre Dame: University of Notre Dame Press, 1989), 66-77, at 72-6; and "Response to the Other", pp. 42f.

53. Conklin, Phenontenology+ pp. 241-45.

54. ConkJin, "A Phenomenological Theory of Human Rights of the Alien" in Erhical Perspectives, 13 (2006), pp. 245-301. 